\title{
IMPLEMENTASI BEKASI SMART CITY: PENGARUH KARAKTERISTIK PENGGUNA TERHADAP PERILAKU KOMUNIKASI PENGGUNA PENGADUAN ONLINE TERPADU (POT)
}

\section{BEKASI SMART CITY IMPLEMENTATION: THE EFFECT OF USERS CHARACTERISTICS ON USERS COMMUNICATION BEHAVIOR OF INTEGRATED ONLINE COMPLAINTS (POT)}

\author{
Tatik Yuniarti ${ }^{1}$, Muhamad Armen ${ }^{2}$ \\ Program Studi Ilmu Komunikasi, Fakultas Komunikasi, Sastra dan Bahasa \\ Universitas Islam “45” Bekasi \\ Jalan Cut Meutia No. 83 Bekasi (17113) \\ Imuhamad.armen@gmail.com, ${ }^{2}$ tatikyuniarti.unisma@gmail.com
}

Diterima : 30 Januari 2020

Direvisi : 24 Februari 2020

Disetujui : 29 Juni 2020

\begin{abstract}
The presence of the Integrated Online Complaints (POT) application created by the Bekasi City Administration provides an opportunity for citizens to submit complaints and reports various problems that occured. However, community participation using this application is still limited. Therefore, this study aimed to identify the influence of POT application users characteristics on their communication behavior to the Bekasi City Administration. This research used an explanatory sequential mixed method with the total sample consisted of 100 people. The results showed that the perception of trust, suitability, and perceived ease of POT users were significantly related to information seeking and information dissemination. This indicated that POT users would disseminate information when they believed the application has helped them in solving problems. Users who felt satisfied and considered the application easy to use also tended to recommend it to relatives, friends and others around their environment. POT users felt that the problems they have been facing were handled more quickly after reporting complaints through the application, However, the communication and response of the Bekasi City Administration were still inadequate.
\end{abstract}

Keywords : Bekasi Smart City, Communication Behavior, Information, Dissemination, Integrated Online Complaints

\begin{abstract}
ABSTRAK
Keberadaan aplikasi Pengaduan Online Terpadu (POT) yang diciptakan oleh Pemerintah Kota Bekasi memberikan peluang bagi warganya untuk menyampaikan pengaduan dan melaporkan pelbagai permasalahan yang terjadi. Akan tetapi, partisipasi masyarakat menggunakan aplikasi ini dinilai masih rendah dilihat dari tingkat penggunaannya. Oleh karena itu, penelitian ini bertujuan untuk mengetahui pengaruh karakteristik pengguna aplikasi POT terhadap perilaku komunikasinya dengan Pemerintah Kota Bekasi. Penelitian ini menggunakan metode penelitian kombinasi (mixed method) dengan sequential explanatory. Sampel pada penelitian ini diperoleh secara purposive dan berjumlah 100 orang. Pengumpulan data dilakukan dengan menggunakan angket dan wawancara. Hasil penelitian menunjukkan bahwa persepsi kepercayaan, kesesuaian, dan persepsi kemudahan pengguna POT berhubungan nyata dengan pencarian informasi dan penyebaran informasi. Hal ini memperlihatkan bahwa pengguna POT akan menyebarkan informasi ketika mereka percaya aplikasi tersebut sudah membantunya dalam menangani masalah. Pengguna yang merasa puas dan mudah dalam menggunakan aplikasi tersebut juga cenderung akan merekomendasikannya kepada kerabat, teman dan orang lain di sekitar lingkungannya. Pengguna POT juga menyatakan bahwa masalah yang dihadapinya lebih cepat tertangani setelah melaporkan pengaduan melalui aplikasi tersebut. Meskipun demikian, komunikasi dan respons Pemerintah Kota Bekasi dinilai masih belum sesuai dengan yang diharapkan.
\end{abstract}

Kata Kunci: Bekasi Smart City, Informasi, Diseminasi, Pengaduan Online Terpadu, Perilaku Komunikasi 


\section{PENDAHULUAN}

Kota Bekasi merupakan salah satu kota di Provinsi Jawa Barat yang menerapkan program Smart City. Firmanyah et al. (2018) mengidentifikasi penerapan smart city dapat dilakukan ketika manusia, sosial, infrastruktur tradisional dan infrastruktur modern (TIK) mendukung pertumbuhan ekonomi dan kualitas hidup. Hal itu dapat dicapai dengan melakukan tata kelola semua sumber daya dengan baik. Target utama konsep ini adalah untuk menghasilkan kota yang nyaman, akses yang mudah ke berbagai layanan dan memiliki kelayakan hidup dari sudut pandang sosial dan lingkungan.

Penerapan Bekasi Smart City dilatarbelakangi oleh proyeksi peningkatan jumlah penduduk di Kota Bekasi pada tahun 2023 yang diperkirakan akan mencapai 3,7 juta jiwa. Jumlah tersebut diprediksi bersumber dari migrasi masuk tiap tahun sebesar rata-rata 45 ribu jiwa (Pemkot Bekasi, 2019). Parasati dalam Firmanyah et al. (2018) menyebutkan bahwa $67 \%$ penduduk di Indonesia tinggal di wilayah perkotaan. Pada tahun 2045 diperkirakan persentasenya akan meningkat menjadi lebih dari $80 \%$.

Salah satu implementasi dari program Bekasi Smart City adalah pembuatan aplikasi Pengaduan Online Terpadu (POT). Pengaduan Online Terpadu (POT) merupakan aplikasi berbasis website bersifat dua arah yang melibatkan partisipasi masyarakat dan digunakan sebagai alat bantu melakukan pengawasan capaian program pembangunan maupun pengaduan masyarakat terkait pelaksanaan program pembangunan Kota Bekasi (Pemkot Bekasi, 2017).

Aplikasi POT yang merupakan media hybrid tersebut pertama kali diperkenalkan kepada masyarakat Kota Bekasi pada 10 Maret
2016, bertepatan dengan "hari ulang tahun ke19 Kota Bekasi" (Setyanti, 2016). Namun, meskipun telah disosialisasikan, pengguna POT di Kota Bekasi masih rendah. Data dari Dinas Komunikasi, Informasi, Statistik, dan Persandian (Diskominfostandi, 2018) sampai dengan tahun 2018 memperlihatkan bahwa jumlah pengguna POT adalah sebanyak 2364 orang. Jika dibandingkan dengan banyaknya usia produktif (15-59 tahun) di Kota Bekasi yang berjumlah 1.988.562, jumlah tersebut terhitung masih jauh dari capaian.

Menurut Carter dan Belanger (2005), faktor-faktor yang memengaruhi keputusan seseorang mengadopsi e-government antara lain adanya persepsi kepercayaan, kesesuaian dan kemudahan. Persepsi kepercayaan merupakan tingkat pemahaman kepercayaan warga, yang mencakup kepercayaan mereka terhadap internet dan pemerintah. Persepsi ini dimiliki oleh warga yang berinisiatif untuk menggunakan e-government. Sementara itu, faktor kesesuaian didefinisikan oleh Mulyasari dalam Sari (2016) sebagai suatu inovasi yang mempunyai sifat kecocokan dan kompatibel dengan inovasi yang digantikannya. Dalam hal ini, pelaporan yang biasanya dilakukan secara langsung berubah menjadi menggunakan aplikasi atau teknologi berbasis internet. Faktor lainnya yakni persepsi kemudahan, yang didefinisikan sebagai pemahaman terhadap penggunaan sarana yang tidak sulit untuk digunakan. Ketiga faktor adopsi tersebut merupakan variabel karakteristik pengguna yang didefinisikan oleh Pala (2014) sebagai ciri-ciri khusus yang melekat pada diri individu, yang pada gilirannya akan membedakan atau menyamakannya dengan individu lainnya. Tingkat karakteristik pengguna tersebut diasumsikan dapat berpengaruh terhadap 
perilaku komunikasinya. Hal tersebut perlu diuji dalam penelitian ini untuk memberikan gambaran tentang faktor-faktor yang menjadi acuan dalam mengimplementasikan aplikasi berbasis e-government di tengah masyarakat.

Rogers (2003) mengemukakan bahwa lima karakteristik inovasi meliputi: (1) relative advantage, merupakan derajat keunggulan suatu inovasi dibanding yang sudah ada sebelumnya, diukur dari segi ekonomi, gengsi, kenyamanan, kepuasan dan lainnya; (2) compatibility, yang merupakan level kesesuaian sebuah inovasi dengan nilainilai yang berlaku, pengalaman masa lalu dan kebutuhan dari adopter; (3) complexity atau kerumitan yakni derajat mudah atau tidaknya sebuah inovasi untuk dipahami dan digunakan adopter; (4) trialability, yakni derajat sebuah inovasi dapat diujicobakan pada lingkup yang terbatas; (5) observability, atau kemampuan untuk diamati adalah derajat yang menunjukkan sejauh mana hasil suatu inovasi dapat terlihat oleh orang lain. Semakin mudah seseorang melihat hasil dari suatu inovasi, semakin besar kemungkinan orang atau kelompok tertentu mengadopsinya. Penggunaan POT sebagai sarana menyampaikan keluhan dan masukan kepada pemerintah daerah menjadi bagian dari inovasi dalam penerapan e-government. Hasil dari inovasi yang diimplementasikan terlihat dari perilaku komunikasi pengguna dalam menggunakan sarana tersebut.

Menurut dokumen ISO 9241-210 dalam Nurazizah (2018), karakteristik pengguna didefinisikan dari pengetahuan, keterampilan, pengalaman, pendidikan, pelatihan, kebiasaan, atribut fisik dan kemampuan. Blackburn dan Cudd (2010) mengemukakan bahwa spesifikasi kebutuhan pengguna erat kaitannya dengan kebutuhan komunikasi efektif dengan berbagai pemangku kepentingan dan sistem yang ada, yang harus dilakukan dalam tahap awal penggunaan dan secara berkelanjutan dievaluasi sebagai proses dalam pengembangan. Hal inilah yang mendasari asumsi adanya hubungan antara karakteristik pengguna POT dengan perilaku komunikasi yang dilakukannya. Could dan Kolb dalam Ichwanudin (1998) mengemukakan perilaku komunikasi adalah segala aktivitas yang bertujuan untuk mencari dan memperoleh informasi dari berbagai sumber dan untuk menyebarluaskan informasi kepada pihak mana pun yang memerlukan. Perilaku komunikasi tersebut mencakup pencarian informasi, penyebaran informasi, dan persepsi kemudahan. Keaktifan warga dalam memberikan masukan dan pengaduan dari program pembangunan menjadi bahan evaluasi dalam menjalankan semua proses pembangunan. Kusumadinata et al. (2015) menyatakan pentingnya peranan komunikasi dalam pembangunan merupakan sebuah syarat majunya sebuah bangsa. Program yang berbasis masyarakat lebih diutamakan, yang ditunjukkan dengan lahirnya beberapa program partisipatif.

Terkait hal tersebut, pengguna POT memiliki perilaku komunikasi yang penting untuk diteliti mengingat keaktifan penggunaannya menjadi indikator dalam mempercepat proses pembangunan. Oleh karena itu, peneliti tertarik untuk mengkaji korelasi karakteristik pengguna dan perilaku komunikasi pengguna POT. Berdasarkan hal tersebut, maka penelitian ini bertujuan untuk menguji korelasi antara karakteristik pengguna POT dan perilaku komunikasinya dengan 
harapan dapat memberikan gambaran tentang faktor-faktor yang dapat dijadikan acuan dalam mengefektifkan aplikasi berbasis e-government di kalangan masyarakat

\section{METODOLOGI PENELITIAN}

Penelitian ini menggunakan metode kombinasi (mixed method) dengan sequential explanatory. Menurut Sugiyono (2017), metode ini menggabungkan metode kuantitatif yang digunakan dalam proses pengumpulan data dan analisis dan metode kualitatif yang digunakan untuk mendapatkan informasi mengenai karakteristik pengguna dan perilaku komunikasi mereka pada aplikasi POT serta klarifikasi kedalaman informasinya dari pihak-pihak terkait. Pengumpulan data dilakukan melalui survei yang melibatkan 100 responden (sampel penelitian) dari jumlah populasi 1890 (hingga Agustus 2018). Analisis terhadap karakteristik pengguna dilakukan berdasarkan pengetahuan, keterampilan, pengalaman, pendidikan, pelatihan, kebiasaan, atribut fisik dan kemampuan (Nurazizah, 2018).

Pengambilan sampel dihitung secara purposif menggunakan rumus Slovin dengan batas kesalahan 10\%. Teknik ini digunakan untuk menentukan sampel berdasarkan kriteria tertentu yang dibuat berdasarkan tujuan penelitian (Kriyantono, 2006). Kriteria sampel ditentukan berdasarkan data laporan dalam aplikasi POT dan pengguna yang telah mengunduh aplikasi tersebut. Hal itu menjadi pertimbangan untuk menguji sejauh mana penggunaan aplikasi POT.

Selain itu, dilakukan pula wawancara untuk melakukan konfirmasi atau memastikan keabsahan data kuesioner yang disebarkan kepada pengguna POT. Proses wawancara dilakukan secara tatap muka dan melalui pesan singkat terstruktur yang disusun secara sistematis (Kriyantono, 2006). Wawancara dilakukan terhadap dua staf e-government Diskominfostandi Kota Bekasi dan lima orang pengguna aplikasi POT yang tinggal di Kota Bekasi. Staf Diskominfostandi Kota Bekasi tersebut dipilih sebagai informan karena memiliki pengetahuan dan pengalaman dalam teknik penggunaan POT sebagai sarana komunikasi Pemerintah Kota Bekasi, sehingga dapat memberikan informasi yang terpercaya.

Sebelum disebarkan, peneliti melakukan uji validitas dan reliabilitas dengan menyebarkan kuesioner atau angket kepada 20 responden yang menggunakan aplikasi Pengaduan Online Terpadu (POT) melalui website di Kota Bekasi. Hasil uji validitas menunjukkan bahwa semua indikator pada penelitian ini dinyatakan valid, karena setiap indikator memiliki $r$ hitung lebih besar daripada $r$ tabel yaitu sebesar $(0,444)$ pada nilai $5 \%$. Sementara itu, hasil uji reliabilitas menunjukkan bahwa interpretasi koefisien semua indikator memiliki nilai Cronbach Alpha $\quad(\sigma)$ sebesar 0,732. Nilai ini menunjukkan bahwa semua pernyataan dalam kuesioner penelitian memiliki hubungan yang tinggi karena terletak pada interval koefisien 0,60-0,80 (Arikunto, 2013).

Teknik analisis data yang digunakan adalah korelasi Rank Spearman untuk mengukur korelasi antara dua variabel, yaitu variabel bebas dan variabel terikat yang berskala ordinal (Ridwan dan Sunarto, 2014). Pada perhitungan menggunakan SPSS, jika nilai signifikansi yang diperoleh $<0,01$ artinya korelasi yang muncul sangat nyata (Ridwan dan Sunarto, 2014). Selain analisis kuantitatif tersebut, dilakukan pula analisis kualitatif melalui triangulasi sumber, yakni dengan melakukan pengecekan dan klarifikasi dari 
hasil penghitungan empiris kepada informan terkait.

\section{HASIL DAN PEMBAHASAN}

\section{Implementasi dan Pengembangan Aplikasi POT Kota Bekasi}

Pengaduan Online Terpadu (POT) merupakan aplikasi berbasis website yang melibatkan partisipasi publik dan bersifat dua arah. Aplikasi ini digunakan sebagai alat bantu untuk melakukan pengawasan capaian program pembangunan maupun pengaduan masyarakat terkait pelaksanaan program pembangunan Kota Bekasi. Pada Gambar 1 tersaji tampilan awal gambaran aplikasi POT Kota Bekasi.

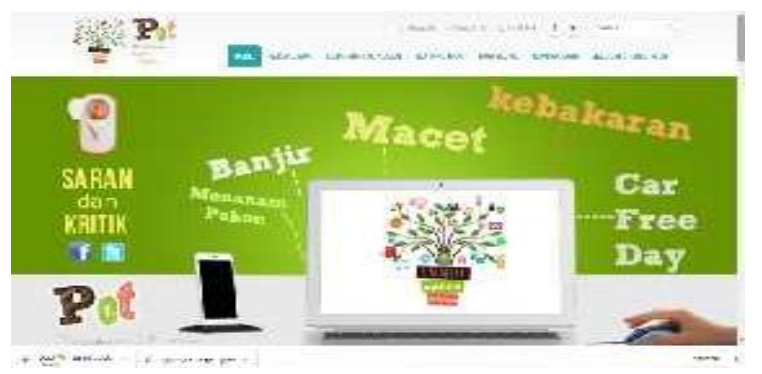

Gambar 1. Tampilan Aplikasi POT Kota Bekasi

Sumber: POT Kota Bekasi. 2018.

Masyarakat dapat berpartisipasi menggunakan POT dengan mengakses website yang beralamat di https://pengaduan.bekasikota.go.id dan juga melalui aplikasi Android dengan mengunduh di Playstore secara gratis. Aplikasi POT baru bisa digunakan oleh pengguna Android saja, sedangkan untuk pengguna IOS belum diintegrasikan. Aplikasi POT mempunyai alur pengaduan dari pelapor hingga dipublikasikan di aplikasi tersebut.

Berdasarkan data dari Diskominfostandi Kota Bekasi, semenjak diluncurkan hingga Desember 2018 pengguna aplikasi POT berjumlah 2364 orang dengan jumlah pengaduan sebanyak 1468 pengaduan. Tercatat sebanyak 47 SKPD terlibat pada aplikasi ini. Ada 42 jenis pengaduan yang bisa dipilih oleh masyarakat, sebagaimana tersaji pada Tabel 1.

Tabel 1. Jenis Pengaduan POT Kota Bekasi

\begin{tabular}{|c|c|c|c|}
\hline No & Jenis Pengaduan & No & Jenis Pengaduan \\
\hline 1 & Parkir Liar & 22 & Akses Wifi \\
\hline 2 & Transportasi & 23 & Lampu PJU \\
\hline 3 & Limbah & 24 & Kebersihan \\
\hline 4 & Banjir & 25 & Pelayanan Publik \\
\hline 5 & RTH & 26 & Parkir \\
\hline 6 & Wifi & 27 & $\begin{array}{l}\text { Ruang Terbuka } \\
\text { Hijau }\end{array}$ \\
\hline 7 & Persampahan & 28 & Pungli \\
\hline 8 & Pungutan Liar & 29 & Orang gila \\
\hline 9 & Infrastuktur & 31 & $\begin{array}{l}\text { Bangunan dan } \\
\text { Pemukiman Liar }\end{array}$ \\
\hline 10 & Kesehatan & 32 & Umum \\
\hline 11 & Pengemis & 33 & Kebakaran \\
\hline 12 & Pohon Tumbang & 34 & $\begin{array}{l}\text { Kependudukan } \\
\text { dan Catatan Sipil }\end{array}$ \\
\hline 13 & Keamanan & 35 & JPO \\
\hline 14 & Ketertiban Pasar & 36 & PDAM \\
\hline 15 & Orang Terlantar & 37 & Pengamen \\
\hline 16 & $\begin{array}{l}\text { Reklame dan } \\
\text { Taman }\end{array}$ & 38 & $\begin{array}{l}\text { Perempuan dan } \\
\text { Anak }\end{array}$ \\
\hline 17 & PKL & 39 & $\begin{array}{l}\text { Jaringan } \\
\text { Telekomunikasi }\end{array}$ \\
\hline 18 & Lingkungan & 40 & Stadion \\
\hline 19 & Lalu Lintas & 41 & Pasar \\
\hline 20 & $\begin{array}{l}\text { Pelayanan } \\
\text { Kesehatan }\end{array}$ & 42 & Ketenagakerjaan \\
\hline 21 & Perizinan & & \\
\hline
\end{tabular}

Pada Gambar 2 tampak jenis pengaduan atau laporan yang paling banyak disampaikan pengguna POT Kota Bekasi.

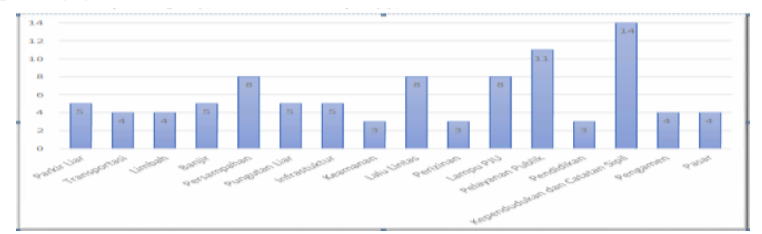

Gambar 2. Jenis Pengaduan Pengguna di Aplikasi POT Kota Bekasi 
Berdasarkan Gambar 2 tersebut, pengaduan terbanyak terkait dengan masalah kependudukan dan catatan sipil, yakni berjumlah 14 pengaduan, sedangkan masalah keamanan, perizinan, dan pendidikan menjadi topik masalah yang paling sedikit disampaikan oleh masyarakat. Namun dari hasil pengamatan di bagian pengaduan POT, masalah pendidikan cenderung meningkat saat momentum tertentu, seperti saat penerimaan siswa baru. Pengaduan lain yang disampaikan antara lain berkenaan dengan persampahan dan lalu lintas dengan delapan pengaduan; lima pengaduan mengenai parkir liar, banjir, pungutan liar, dan infrastruktur; dan empat pengaduan mengenai transportasi, limbah, pengamen dan pasar.

Teknologi aplikasi Pengaduan Online Terpadu akan terus ditingkatkan mengikuti perkembangan. Selain itu, POT juga akan tergabung dan terintegrasi dengan aplikasi serupa berskala nasional yaitu LAPOR! (Layanan Aspirasi dan Pengaduan Online Rakyat). Terintegrasinya aplikasi POT dengan LAPOR! diharapkan bisa meningkatkan partisipasi masyarakat untuk mengadukan permasalahan atau menyampaikan aspirasinya kepada pemerintah setempat, sehingga pembangunan di Indonesia akan merata. A dan $\mathrm{R}$, staf e-government Diskominfostandi Kota Bekasi menyatakan, harapan dari terintegrasinya dua aplikasi ini adalah masyarakat tidak perlu repot lagi untuk memasang dua aplikasi pada smartphone-nya karena cukup satu aplikasi bisa digunakan di berbagai tempat. Selain itu, dengan diintegrasikannya aplikasi POT ke aplikasi LAPOR! maka masyarakat Kota Bekasi pengguna IOS dapat menggunakan LAPOR!

\section{Karakteristik Pengguna POT Kota Bekasi}

Karakteristik pengguna POT diteliti berdasarkan parameter dokumen ISO 9241210 yang menyebutkan adanya pengetahuan, keterampilan, pengalaman, pendidikan, pelatihan, kebiasaan, atribut fisik dan kemampuan.

Bentuk atribut fisik dalam penelitian adalah kepemilikan media untuk mengakses internet dan media sosial yang tergambar pada Gambar 3 dan 4.

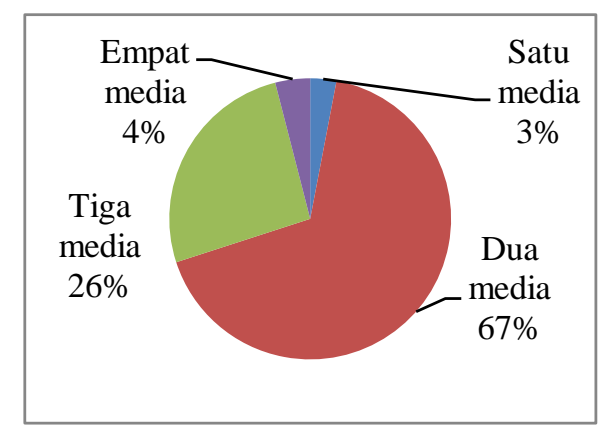

Gambar 3. Kepemilikan Media Akses

$$
\text { Internet }
$$

Berdasarkan Gambar 3 tersebut, sebagian besar pengguna POT Kota Bekasi, yaitu sebanyak 67 orang (67\%), memiliki dua perangkat untuk mengakses internet dan paling sedikit memiliki satu media akses internet yaitu sebanyak 3 orang (3\%). Pada umumnya, responden mempunyai lebih dari satu perangkat yang digunakan untuk mengakses internet, yaitu smartphone, tablet, laptop, dan komputer. Ada yang menggunakan dua smartphone serta satu komputer sekaligus, ada juga yang mempunyai laptop, komputer rumah, dan juga smartphone. Hal ini berhubungan dengan pekerjaan responden yang sebagian besar merupakan pegawai swasta dan mahasiswa sehingga mereka mempunyai lebih dari satu media untuk mengakses internet. 
Sementara itu, kepemilikan media sosial responden penelitian dapat dilihat pada Gambar 4.

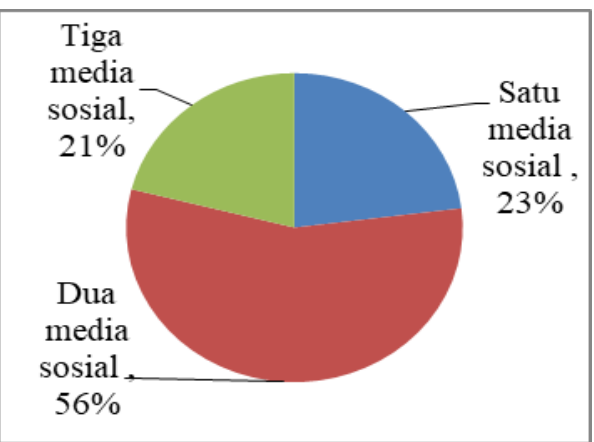

Gambar 4. Kepemilikan Media Sosial

Dari Gambar 4 diketahui bahwa persentase terbanyak responden mempunyai dua media sosial yaitu sebanyak 56 orang (56\%), sedangkan persentase paling sedikit memiliki tiga media sosial, yakni sebanyak 21 orang (21\%). Hasil survei menunjukkan bahwa kepemilikan media sosial terbanyak adalah pada akun Facebook dan Instagram. Hampir semua responden mempunyai akun Facebook, hasil ini sesuai dengan data yang dikeluarkan We Are Social dan Hootsuit pada tahun 2018 bahwa Indonesia menempati posisi keempat sebagai negara dengan pengguna Facebook terbanyak di dunia. Dalam hal ini, Kota Bekasi merupakan kota dengan pengguna Facebook terbesar nomor tiga di dunia. Media sosial lain yang dimiliki responden yaitu Instagram serta Twitter.

\section{Persepsi Pengguna terhadap Keberadaan POT Kota Bekasi}

Persepsi pengguna POT yang diteliti diadopsi dari hasil penelitian Carter dan Belanger (2005) yang menyatakan bahwa persepsi kepercayaan, kesesuaian, dan persepsi kemudahan merupakan faktor penentu adopsi e-government di masyarakat.
Hal ini juga sesuai dengan parameter lain pengguna POT yakni adanya pengetahuan, keterampilan, pengalaman, pendidikan, pelatihan, kebiasaan, dan kemampuan.

Persepsi kepercayaan pada penelitian ini didefinisikan sebagai tingkat persepsi kepercayaan warga, yang mencakup persepsi kepercayaan terhadap internet dan pemerintah. Persepsi kepercayaan yang dimaksud dalam penelitian ini merupakan pemahaman terhadap penyediaan saluran informasi berbasis internet oleh pemerintah setempat. Persepsi kepercayaan yang dimiliki oleh warga akan memengaruhi mereka dalam menggunakan aplikasi POT. Gambar 5 menggambarkan bahwa persentase terbanyak (39\%) responden menyatakan setuju bahwa aplikasi POT yang berbasis internet akan lebih efektif dan efisien. Adapun yang paling sedikit (2\%) menyatakan sangat tidak setuju apabila dikatakan bahwa aplikasi POT yang berbasis internet akan lebih efektif dan efisien.

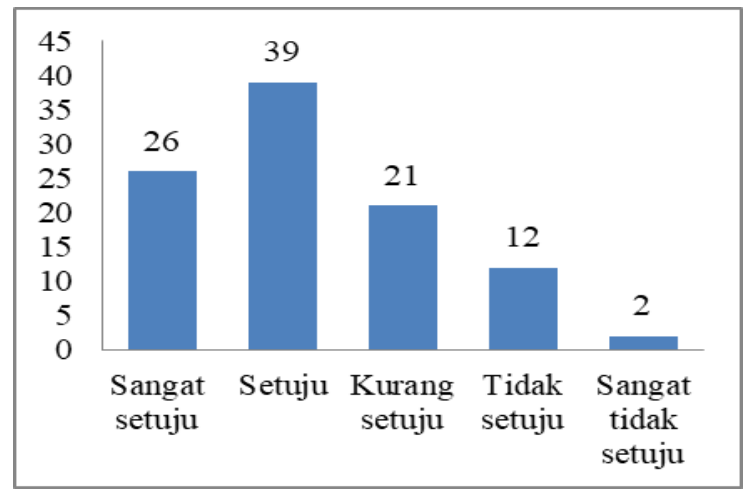

Gambar 5. Persepsi Kepercayaan

Pengguna yang menyatakan setuju percaya bahwa aplikasi POT merupakan saluran informasi berbasis internet yang disediakan oleh Pemerintah Kota Bekasi. Aplikasi ini dinilai penggunanya lebih mudah dan praktis untuk melaporkan pengaduan, menyampaikan aspirasi dan informasi serta 
berinteraksi dengan pemerintah setempat. Aplikasi ini diyakini mampu menjembatani pengaduan dengan cepat sehingga mereka mau mencobanya. Hal ini juga disampaikan oleh salah satu pengguna, Q (24 tahun) yang mencoba aplikasi POT karena percaya terhadap program berbasis internet.

"Iya, lebih percaya dan enak yang berbasis online gitu karena lebih praktis, dibanding dateng langsung lebih ribet birokrasinya. Ketika ada aplikasi POT, ya saya coba sambil dilihat bagaimana progresnya, apa ini terealisasi, bisa benar membantu masyarakat” [Q, 2018].

Sementara itu, persepsi kesesuaian didefinisikan sebagai layanan e-government yang bersesuaian dengan kebiasaan dan kebutuhan warga. Salah satunya, menurut Maditinos et al. (2011), adalah dengan mengembangkan aplikasi POT yang sesuai dengan kebutuhan. Menurut A dan R, staf di bidang e-government Diskominfostandi Kota Bekasi, aplikasi POT tersebut dikelola dan dikontrol langsung oleh staf Pemerintah Kota Bekasi untuk memberikan layanan kepada masyarakat,

"Aplikasi POT itu kita sendiri yang
mengelola, kita juga yang
mengawasi, kita punya sendiri,
kontrol ada di kita, itu kan saya bila
makannya tergantung APBD juga
gitu karena kita terbatas, cuman kita
jadinya gak manja, gak bergantung
sama orang" [A, R., 2018]

Dari sisi jumlah pengguna, A dan $\mathrm{R}$ mengungkapkan bahwa POT sudah diunduh satu juta kali, namun masalahnya jumlah pengaduan tersebut harus bisa teratasi.
Keberadaan POT tersebut menurutnya diharapkan memang bisa menjadi sarana yang tepat bagi masyarakat untuk menyampaikan pengaduan atau keluhan supaya permasalahan cepat teratasi.

Pada Gambar 6 tampak tingkat persepsi pengguna terhadap kesesuaian aplikasi POT dengan kebutuhan.

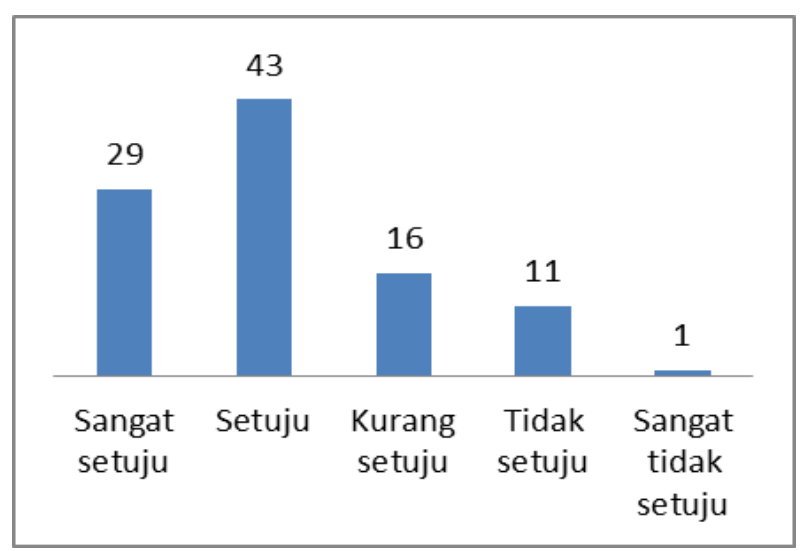

Gambar 6. Persepsi Kesesuaian

Pada Gambar 6 tersebut terlihat bahwa proporsi terbanyak (43\%) pengguna POT Kota Bekasi menyatakan bahwa keberadaan aplikasi telah sesuai dengan kebutuhan yang selama ini diperlukan masyarakat, terutama dalam menyampaikan keluhan dan permasalahan kepada Pemkot Bekasi. Aplikasi POT merupakan bentuk inovasi yang dilakukan oleh Pemkot Bekasi yang muncul akibat sulitnya proses pengaduan yang dilakukan masyarakat. Hal itu disampaikan salah satunya oleh A (40 tahun) yang menuturkan tentang permasalahan ketersediaan air bersih di rumahnya. Awalnya, dia melaporkan masalah itu kepada PDAM namun tidak ada tanggapan. Lalu dia mencari sarana pengaduan lain di internet dan menemukan aplikasi POT sehingga dia melaporkan permasalahannya pada aplikasi tersebut. 
Hal tersebut senada dengan pernyataan pengguna POT lainnya yaitu D (25 tahun) yang mengeluhkan permasalahan sampah yang sudah menumpuk namun tidak kunjung diangkat oleh petugas kebersihan. D menyampaikan keluhan ini kepada petugas RT maupun RW di lingkungannya, namun tidak ada kelanjutan dari laporan yang diadukan. Oleh karena itu, dia mencoba mencari pelayanan lain yang dapat menjawab kebutuhannya, yaitu melalui pengaduan terpadu di Bekasi, sehingga kemudian dia menemukan aplikasi POT. D mengatakan aplikasi POT ini sesuai kebutuhan karena proses pengaduan ditangani sangat cepat, yakni hanya dalam waktu satu hari sejak pelaporan. Permasalahannya langsung ditindaklanjuti oleh petugas terkait. Hal ini sama seperti yang dituturkan A dan $\mathrm{R}$ selaku staf Diskominfostandi yang juga merupakan operator aplikasi POT, bahwa tujuan pengembangan media tersebut adalah agar dapat mempercepat penanganan masalah pembangunan di Kota Bekasi. Persoalan administrasi bisa cepat tertangani, namun hal yang berhubungan dengan perbaikan pembangunan membutuhkan waktu karena terkait dengan biaya.

"Cuman masalahnya pengaduan di POT ini kan ada yang bersifat administrasi dan teknis, kalo administrasi kan cepet ditangani tapi kalo yang teknis itu kan mungkin perlu waktu, itu kadangkadang masyarakat gak sabaran, misalnya ada pengaduan jalan yang berlubang, nah itu kan yang butuh koordinasi mengenai anggaran provinsi, anggaran nasional" [A,R, 2018].
Selain persepsi kepercayaan dan kesesuaian, penelitian ini juga mengukur persepsi kemudahan. Gambar 7 menunjukkan gambaran persepsi kemudahan pengguna POT Kota Bekasi. Pada Gambar 7 diketahui bahwa sebanyak $38 \%$ dari sampel penelitian menyatakan sangat setuju dengan kemudahan penggunaan aplikasi POT Kota Bekasi.

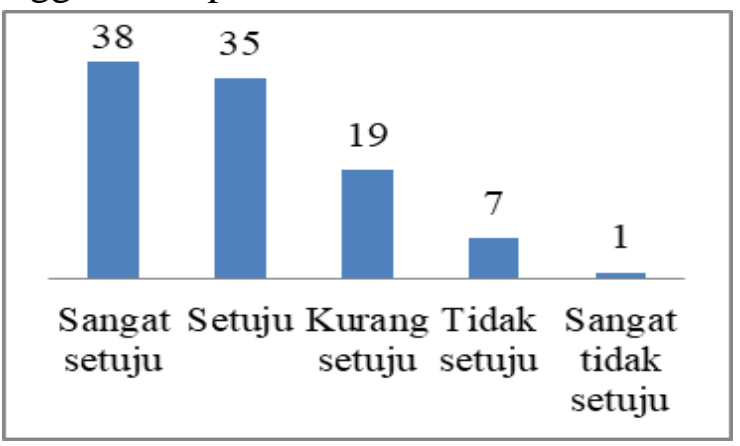

Gambar 7. Persepsi Kemudahan

Persepsi kemudahan yang dirasakan pada penggunaan aplikasi POT terletak pada mudahnya pengoperasian fitur menu yang berada di dalamnya. Hal itu seperti yang disampaikan oleh A (19 tahun) yang mengatakan bahwa setelah mengetahui aplikasi tersebut dia bisa langsung dapat menggunakannya.

"Gampang banget makenya, saya baru sekali tahu dan install langsung coba dan bisa menggunakannya, kan itu soalnya cuman daftar email terus nama aja. Di situ juga saya bisa dengan mudah nyembunyiin identitas saya kalau lagi melaporkan permasalahan" [A, 2019].

\section{Perilaku Komunikasi Pengguna POT Kota Bekasi}

Perilaku komunikasi terdiri dari pencarian informasi dan penyebaran informasi. Ellis dalam Ilmi (2014) 
menyatakan bahwa kegiatan pencarian informasi seseorang didorong oleh keadaan orang tersebut yang memiliki pengetahuan yang kurang sehingga berkeinginan untuk menambah referensi informasi mengenai sesuatu yang sedang dibutuhkan. Salah satu parameter dari pencarian informasi adalah sumber informasi dan keabsahan informasi. Berdasarkan hasil survei, sumber informasi yang paling banyak digunakan oleh pengguna adalah internet, sedangkan pencarian informasi yang berasal dari informasi personal sangat rendah. Sebanyak $51 \%$ pengguna yang menjadi responden menyatakan setuju bahwa pencarian informasi mengenai aplikasi POT mudah ditemukan di internet dan informasi yang didapatkan merupakan informasi yang terpercaya.

Sementara itu, penyebaran informasi yang dimaksud dalam penelitian ini adalah penyebaran pesan yang berisi fakta (Sabaruddin, 2008). Variabel yang diukur antara lain adalah tujuan, sasaran, dan intensitas penyebaran informasi mengenai aplikasi POT. Berdasarkan survei yang dilakukan didapatkan fakta bahwa $40 \%$ pengguna menyatakan setuju untuk menyebarkan informasi mengenai aplikasi POT setelah menggunakannya. Jawaban kurang setuju diartikan bahwa pengguna baru mau menyebarkan informasi mengenai aplikasi POT apabila pengaduannya telah ditanggapi. Penyebarannya pun hanya dilakukan kepada beberapa orang saja. Inilah yang membuat banyak masyarakat belum mengetahui tentang aplikasi tersebut.

Pengguna menyebarkan informasi mengenai aplikasi POT kepada orang-orang di sekitar mereka ketika mereka sudah menggunakan aplikasi ini. Akan tetapi, penyebaran informasi tersebut hanya dilakukan lewat mulut ke mulut (words of mouth) ketika orang lain membutuhkan. Hal ini dikonfirmasi oleh pernyataan salah satu pengguna, D (25 tahun), yang menyebarkan informasi kepada teman sekantornya, yang juga tinggal di Kota Bekasi.

"Saya ngasih tau temen-temen saya di kantor mengenai aplikasi POT ini, cuman hanya sekedar ngasih tau aja, saya juga engga tau mereka menggunakannya apa engga setelah itu” (D, 2019).

\section{Hubungan antara Karakteristik Pengguna Aplikasi POT dengan Perilaku Komunikasi}

Hubungan antara karakteristik pengguna aplikasi POT akan dibahas pada subbab ini. Tabel 2 akan menggambarkan hubungan antara persepsi kepercayaan dengan perilaku komunikasi.

Tabel 2. Hubungan antara Persepsi Kepercayaan dengan Perilaku Komunikasi

\begin{tabular}{|c|c|c|}
\hline \multirow{2}{*}{$\begin{array}{c}\text { Karakteristik } \\
\text { Pengguna }\end{array}$} & \multicolumn{2}{|c|}{ Perilaku Komunikasi } \\
\cline { 2 - 3 } & Pencarian Informasi & Penyebaran Informasi \\
\hline \multirow{2}{*}{$\begin{array}{c}\text { Persepsi } \\
\text { kepercayaan }\end{array}$} & $0,926^{*}$ & $\mathrm{R}$ \\
\hline \multicolumn{2}{|c|}{$* * a .<0,01$} & Berhubungan Sangat Nyata \\
\hline
\end{tabular}

Berdasarkan Tabel 2, hubungan antara persepsi kepercayaan dengan pencarian informasi menunjukkan nilai 0,926 dengan signifikansi $<0,01$. Artinya, persepsi kepercayaan berhubungan sangat nyata dan sangat kuat dengan pencarian informasi. Hasil hubungan ini menjelaskan bahwa responden yang percaya dengan program berbasis internet akan cenderung mencari informasi 
mengenai pelayanan tersebut, baik di internet maupun secara personal, kepada orang lain. Hasil ini menyatakan bahwa rasa percaya yang responden rasakan akan memengaruhi kecenderungan responden menemukan layanan pengaduan lain di internet ketika pengaduan dengan cara konvensional tidak membuahkan hasil. Mereka tetap berusaha mencari layanan pengaduan yang disediakan pemerintah untuk mengatasi permasalahan yang dialami.

Tabel 2 juga menunjukkan bahwa hubungan antara persepsi kepercayaan dengan penyebaran informasi menunjukkan nilai 0,924 dengan signifikansi $<0,01$. Nilai 0,924 dalam tabel korelasi Rank Spearman menunjukkan nilai sangat kuat. Hal ini berarti bahwa responden akan menyebarkan informasi mengenai aplikasi POT ketika mereka percaya aplikasi POT ini sudah membantunya dalam menangani masalah.

Sementara itu, hubungan antara kesesuaian dengan perilaku komunikasi dapat dilihat pada Tabel 3.

Tabel 3. Hubungan antara Persepsi Kesesuaian dengan Perilaku Komunikasi

\begin{tabular}{|c|c|c|}
\hline \multirow{2}{*}{$\begin{array}{c}\text { Karakteristik } \\
\text { Pengguna }\end{array}$} & \multicolumn{2}{|c|}{ Perilaku Komunikasi } \\
\cline { 2 - 3 } & $\mathrm{R}$ & $\begin{array}{c}\text { Penyebaran } \\
\text { Informasi }\end{array}$ \\
\cline { 2 - 3 } & $0,935^{* *}$ & $\mathrm{R}$ \\
\hline Kesesuaian & $* * a .<0,01$ & $\begin{array}{c}\text { Berhubungan } \\
\text { Sangat Nyata }\end{array}$ \\
\hline
\end{tabular}

Sebagaimana tampak pada Tabel 3, hubungan antara kesesuaian dengan pencarian informasi memiliki nilai 0,935 dengan signifikansi $<0,01$. Nilai 0,935 dalam tabel korelasi Rank Spearman merupakan nilai sangat kuat, sedangkan signifikansi $<0,01$ menyatakan bahwa hubungan yang terbentuk sangat nyata. Artinya, persepsi pengguna terhadap kesesuaian berhubungan sangat nyata dan sangat kuat dengan pencarian informasi. Adanya hubungan kuat dan sangat nyata antarvariabel tersebut terjadi karena responden merasa ketika sebuah inovasi seperti aplikasi POT sesuai dengan kebutuhan mereka maka mereka akan mencari informasi mengenai aplikasi POT tersebut sebelum menggunakannya. Hal ini disampaikan A (40 tahun) yang mencari aplikasi POT karena didasari kebutuhan untuk memecahkan permasalahan air bersih yang sedang dialaminya. Awalnya dia melaporkan kepada PDAM namun tidak ada tanggapan hingga kemudian mencari pengaduan lain di internet dan menemukan aplikasi POT untuk melaporkan permasalahan tersebut.

Tampak pada Tabel 3 tersebut, hubungan antara kesesuaian dengan penyebaran informasi menghasilkan nilai 0,890 dengan signifikansi <0,01. Nilai 0,890 dalam tabel korelasi Rank Spearman menunjukkan nilai kuat, sedangkan signifikansi $<0,01$ menyatakan bahwa hubungan yang terjadi sangat nyata. Artinya, persepsi pengguna terhadap kesesuaian berhubungan sangat nyata dan sangat kuat dengan penyebaran informasi. Hasil hubungan yang sangat nyata dan kuat diartikan bahwa responden yang merasa aplikasi POT telah menjawab kebutuhannya akan merekomendasikan aplikasi tersebut kepada kerabat, teman, dan orang lain di sekitar lingkungannya. Hal ini sesuai dengan pernyataan salah satu responden bernama D (25 tahun) yang menyebarkan informasi mengenai aplikasi POT kepada teman-teman dan kerabatnya karena aplikasi tersebut sesuai 
dengan kebutuhannya. Selain itu, aplikasi POT juga sudah membantunya menangani permasalahan yang dihadapi.

Selain persepsi kepercayaan dan kesesuaian, diukur pula hubungan antara persepsi kemudahan dengan perilaku komunikasi. Tabel 4 menunjukkan hubungan persepsi kemudahan dengan perilaku komunikasi.

Tabel 4. Hubungan Persepsi Kemudahan dengan Perilaku Komunikasi

\begin{tabular}{|c|c|c|}
\hline \multirow{2}{*}{$\begin{array}{c}\text { Karakteristik } \\
\text { Pengguna }\end{array}$} & Pencarian Informasi & $\begin{array}{c}\text { Penyebaran } \\
\text { Informasi }\end{array}$ \\
\cline { 2 - 3 } & $\mathrm{R}$ & $\mathrm{R}$ \\
\hline $\begin{array}{c}\text { Persepsi } \\
\text { kemudahan }\end{array}$ & $0,877 * *$ & $0,872 * *$ \\
\hline \multicolumn{2}{|c|}{$* * a .<0,01$} & $\begin{array}{c}\text { Berhubungan } \\
\text { Sangat Nyata }\end{array}$ \\
\hline
\end{tabular}

Berdasarkan Tabel 4 diketahui bahwa nilai hubungan antara persepsi kemudahan yang dirasakan dalam pencarian informasi sebesar 0,877 dengan signifikansi sebesar $<0,01$. Signifikansi $<0,01$ menunjukkan bahwa ada hubungan sangat nyata sedangkan nilai 0,877 dalam tabel korelasi Rank Spearman menunjukkan nilai sedang. Artinya, persepsi kemudahan yang dirasakan berhubungan nyata dan sedang dengan pencarian informasi.

Hal ini berarti bahwa dalam melakukan pencarian informasi mengenai sebuah layanan, responden lebih mengedepankan kepercayaan dan kebutuhan mereka sehingga menghasilkan hubungan sedang, karena persepsi kemudahan menggunakan aplikasi menjadi alasan pendukung mengapa aplikasi itu dicari dan digunakan. Hal ini ditunjang oleh pernyataan responden A (40 tahun) yang mengatakan bahwa tujuannya mencari informasi mengenai aplikasi pengaduan dilatarbelakangi oleh manfaat dan kebutuhannya.

"Kalau saya mencari informasi
mengenai aplikasi karena emang
kebutuhan karena waktu itu mau
ngadu masalah air yang bermasalah
di rumah gak keluar, terus saya cari
ngadu lewat apa dan tahu mengenai
aplikasi POT ini, kalau aplikasi itu
mudah digunain juga jadi satu alasan
karena supaya efisien dan efektif tapi
bukan alasan utama" (A, 2018).

Pada Tabel 4 juga diketahui bahwa hubungan antara persepsi kemudahan yang dirasakan dengan penyebaran informasi memiliki nilai 0,872 dengan signifikansi $<0,01$. Signifikansi $<0,01$ menunjukkan bahwa ada hubungan yang nyata. Adapun nilai 0,872 dalam tabel korelasi Rank Spearman menunjukkan nilai yang kuat. Artinya, persepsi kemudahan yang dirasakan berhubungan kuat dan sangat nyata dengan penyebaran informasi.

Hal ini memperlihatkan bahwa keputusan pengguna untuk menyebarkan informasi mengenai aplikasi POT dipengaruhi oleh kemudahan pemakaiannya. Hal itu disebabkan banyak orang kesulitan dalam menggunakan aplikasi sehingga mereka cenderung memilih aplikasi yang mudah digunakan agar efisien. Hal ini disampaikan oleh responden A (51 tahun) yang mendapat informasi mengenai aplikasi POT dari anaknya. Saat pertama kali menggunakan aplikasi tersebut, dirinya merasakan kemudahan untuk memahami sehingga menyampaikan informasi tersebut ke tetangganya.

"Kemarin pas ada masalah di gang mana, saya lupa, ada yang nanya ke saya, ini patungannya berapa ya buat 
perbaikin gorong-gorong? Terus saya bilang, gak usah patungan, ini ada aplikasi POT dari pemerintah. Gampang dipake cuman isi nama email, terus isi pengaduannya, besoknya langsung dateng orangnya" (A, 2019).

\section{KESIMPULAN DAN SARAN}

Persepsi kepercayaan dan kesesuaian pengguna aplikasi POT memiliki hubungan yang nyata dan sangat kuat dengan perilaku komunikasi. Artinya, jika pengaduan yang disampaikan warga melalui aplikasi tersebut ditanggapi serius, maka akan timbul kepercayaan yang berefek pada perilaku komunikasinya, seperti menyampaikan pengalamannya kepada orang lain. Persepsi kesesuaian berhubungan sangat nyata dan kuat dengan perilaku komunikasi yakni pada pencarian dan penyebaran informasi. Hal itu membuktikan bahwa ketika responden merasa bahwa sebuah inovasi seperti aplikasi POT sesuai dengan kebutuhannya, maka muncul niat untuk mencari informasi mengenai aplikasi POT tersebut dan merekomendasikan aplikasi tersebut kepada kerabat, teman dan orang lain di sekitar lingkungannya. Persepsi kemudahan juga berhubungan sangat nyata dengan perilaku komunikasi. Maknanya adalah bahwa responden akan menyebarkan informasi mengenai aplikasi POT apabila sudah merasakan kemudahan dalam pemakaiannya.

Berdasarkan hasil penelitian tersebut, peneliti mengusulkan kepada Pemerintah Kota Bekasi dan pemerintah daerah lain yang sudah memiliki aplikasi POT maupun tools sejenis agar lebih menekankan aspek kemudahan penggunaan. Aplikasi yang ramah pengguna (user friendly) akan menjadikannya sarana untuk menyampaikan segala macam pengaduan. Sebaliknya, jika sulit digunakan atau terlalu rumit, maka aplikasi tersebut akan cenderung tidak digunakan.

Hal ini sangat penting bagi keberlangsungan komunikasi dan percepatan proses pembangunan yang sedang dijalankan. Sosialisasi perlu terus-menerus dilakukan baik melalui kegiatan yang diselenggarakan oleh Pemerintah Kota maupun yang diadakan oleh komunitas, misalnya Karang Taruna. Pemanfaatan media sosial juga bisa lebih dioptimalkan untuk menyosialisasikan aplikasi tersebut.

\section{UCAPAN TERIMA KASIH}

Terima kasih penulis sampaikan kepada Unisma Bekasi yang telah mendukung penelitian ini, serta jajaran Dinas Komunikasi, Informasi, Statistik dan Persandian (Diskominfostandi) Kota Bekasi atas informasi dan data yang sudah diberikan. Tak lupa, penulis juga menghaturkan terima kasih kepada LPDP (Lembaga Pengelola Dana Penelitian) BUDI DN.

\section{DAFTAR PUSTAKA}

Arikunto (2013). Prosedur Penelitian: Suatu Pendekatan Praktik. Jakarta: Rineka Cipta.

Blackburn, S., Cudd, P. (2010). An Overview of User Requirements Specification in ICT Product Design, Association For the Advancement of Assistive Technology in Europe: The Social Model For AT Technology Transfer (hal 9-12). Sheffield, UK.

Carter, L., Belanger, F. (2005) The utilization of e-government services: Citizen trust, innovation and acceptance factors. Inf. 
Syst. J. 15 (1): 5-25.Doi:10.1111/j.13652575.2005.00183. $\mathrm{x}$

Diskominfostandi Kota Bekasi. (2018). Tentang aplikasi pengaduan online terpadu. Tersedia pada:https://pengaduan.bekasikota.go.id/ home\#tentang_kami.

Firmanyah, R. S., Supangkat, S. H., Arman, A. A., \& Adhitya, R. (2018). Searching smart city in Indonesia through maturity model analysis: (Case study in 10 cities). International Conference on ICT for Smart Society, ICISS 2017, 2018January, $1-6$. https://doi.org/10.1109/ICTSS.2017.8288 880.

Ichwanudin. (1998). Hubungan Perilaku Komunikasi Peserta Kelompok Penggerak Pariwisata (Kompepar) Dengan Adopsi Program Sapta Pesona di Kabupaten Sukabumi. Bogor: Institut Pertanian Bogor. Tersedia pada: https://repository.ipb.ac.id/bitstr eam/handle/123456789/21217/1998ich.p $\mathrm{df}$ ? sequence $=2 \&$ isAllowed $=\mathrm{y}$.

Kriyantono, R. (2006). Teknik Praktis Riset Komunikasi. Jakarta: Kencana Prenada Media Group.

Kusmadinanta, A. A., Sarwoprasodjo, S., Purnaningsih, N. (2012). Analisis Komunikasi Partisipasi dalam Penyelenggaraan Program Perbaikan Gizi Masyarakat (Studi Kasus pada Kelompok Gizi Masyarakat Pulokerto Kota Palembang). Jurnal Komunikasi Pembangunan. 10 (2): 30-42.

Maditinos, D., Chatzoudes, D., Tsairidis, C. (2011). Factors affecting ERP system implementation effectiveness. Journal of Enterprise Information Management, 25(1), $60-78$. https://doi.org/10.1108/17410391211192 161.

Nurazizah, S. (2018). Rancangan Prototipe Mockup Sistem Informasi Manajemen Pada Biro Travel UINSA. Surabaya: Universitas Islam Negeri Sunan Ampel.

Pala, R. (2014). Penggunaan Internet dan Kategori Sosial Penggunanya. Makassar: BBPPKI Makassar Balitbang SDM Kementerian Kominfo. Tersedia pada:

https://media.neliti.com/media/publicatio ns/133583-ID-penggunaan-. internetdan-kategori-sosial.pdf).

Pemerintah Kota Bekasi. (2017). Konsep smart city menyelesaikan persoalan perkotaandengan cara Thingking Out of the Box. Tersedia pada: https://www.bekasikota.go.id/detail/kons ep-smart-city-menyelesaikan-persoalanperkotaan-dengan-cara-thinking-out-ofthe-box.

Pemerintah Kota Bekasi. (2019). Peraturan Daerah Kota Bekasi Nomor 08 Tahun 2019 Tentang Rencana Pembangunan Jangka Menengah Daerah Tahun 20182023. Bekasi: Pemkot Bekasi.

Ridwan dan Sunarto. (2014). Pengantar Statistika Untuk Penelitian: Pendidikan, Sosial, Komunikasi, Ekonomi, dan Bisnis. Cetakan Ke-7. Bandung: Alfabeta.

Rogers, E. (2003). Diffusion of Innovation. $5^{\text {th }}$ Edition. New York: Free Press.

Sabaruddin. (2008). Hubungan Antara Penyebaran Informasi Dengan Tingkat Pengetahuan, Sikap, dan Perilaku Nelayan Dalam Pelestarian Terumbu Karang di Kabupaten Pangkep (Studi Difusi Informasi). Tesis. Makassar: Universitas Hasanudin. 
Implementasi Bekasi Smart City: Pengaruh Karakteristik Pengguna Terhadap Perilaku Komunikasi...

Sari, A., K. (2016). Pengaruh Inovasi, Kesesuaian, Keunggulan Relatif dan

Mandiri di Surabaya. Sekolah Tinggi Ilmu Ekonomi Perbanas. Surabaya. Tersedia pada:

http://eprints.perbanas.ac.id/2180/1/ART IKEL\%20ILMIAH.pdf.

Setyanti, E., P. (2016) Ulang Tahun ke-19, Bekasi Luncurkan Aplikasi Smart City. Tersedia
Persepsi Kegunaan Terhadap Adopsi Internet Banking Bagi Nasabah Bank https://www.rappler.com/indonesia/1254 74-ulang-tahun-bekasi-smart-city).

Diakses pada Senin, 14 Januari 2019 pukul 14.15

Sugiyono. (2017). Metode Penelitian Kombinasi (Mixed Methods). Bandung: Alfabeta. 
Jurnal PIKOM (Penelitian Komunikasi dan Pembangunan)

Vol. 21 No. 2 Desember 2020 